\title{
Studies in Blood Coagulation, Diet, and Ischaemic Heart Disease in Two Population Groups in India
}

\author{
S. L. MALHOTRA* \\ From the Medical Department, Western Railway, Churchgate, Bombay, India
}

Thomas et al. (1960) have emphasized that the blood factor is of greater importance than the atherosclerotic plaque (local factor) in thrombus formation. The nature of the postulated haematological factor is not yet known and the relationship of findings of several workers (Merskey, Gordon, and Lachner, 1960; Poole, 1962; Gupta and Rai, 1963) regarding coagulation, to the significantly different incidence of thrombosis in various geographic areas, is still uncertain.

There are big differences in the incidence of ischaemic heart disease between South Indians and North Indians (Padmavati, 1962; Malhotra, 1967a). Among railway employees in the trade of sweeper the disease is 15 times more common in men from South India as compared with those from North India (Malhotra, 1967b). We therefore considered it profitable to look for any significant differences in the haematological factors of the circulating blood between these two population groups.

\section{SUBJECTS AND METHODS}

The subjects were age-matched railway employees in the trade of sweeper from Udaipur (North Indians) and Madras (South Indians) (Fig.). All the tests were carried out in an identical way with the same person observing the end-point. We used the same glassware, syringes, needles, and water-bath for our work which was done separately at Udaipur and Madras, the entire equipment being carried from one place to the other.

Blood samples were collected in the morning each day at the same hour, in batches of 7 . The subjects were fasted overnight, and had neither smoked nor undertaken any physical exertion before being bled. Using the two-syringe technique and an 18-gauge steel needle with the subject lying supine, $7 \mathrm{ml}$. of the blood from the same antecubital venepuncture as was used for the lipid studies reported elsewhere (Malhotra, 1967c) was

Received June 2, 1967.

* Present address: Chief Medical Officer, Southeastern Railway, Garden Reach, Calcutta 43, India. allowed to flow into a non-siliconized $10 \mathrm{ml}$. glass syringe following the method of Eichelberger (1965). It was transferred into plain glass, non-siliconized testtubes, $13 \times 100 \mathrm{~mm}$., bearing a marking of $1 \mathrm{ml}$., and kept in the water-bath at $37^{\circ} \mathrm{C}$, as follows: $1 \mathrm{ml}$. each into 4 test-tubes for determining the clotting time; 1 $\mathrm{ml}$. into another test-tube for determining clot retraction; the remaining $2 \mathrm{ml}$. was used for other determinations including serum proteins, platelet numbers, and platelet adhesiveness.

Whole blood clotting time was measured by the modified Lee and White (1913) method as applied by Eichelberger (1965), using non-siliconized tubes which were tilted through a $45^{\circ}$ angle, every half minute instead of every one minute. This method gives shorter clotting times than the technique in which tubes are tilted every one minute.

Clot lysis was measured by the "tapping" method of Malhotra (1966). This method measures the speed and the amount of spontaneous disintegration of clots in vitro.

Clot retraction was determined semiquantitatively by the method of Stefanini (1950), as applied by Eichelberger (1965).

Platelet counts were done by the method of Rees and Ecker (1923), and platelet adhesiveness by a modification of the method of Rovatti (1951), the modification consisting in adding brilliant cresyl-blue to the diluting fluid to make a 1 per cent solution and the use of venous blood instead of capillary blood.

\section{ResUlts}

Dietary Factors. The results of the dietary survey of the two groups are summarized in Table I. The mean consumption of fats in our Udaipur group was $75 \mathrm{~g}$., against $7 \mathrm{~g}$. in our Madras group. The fats in our Udaipur group were derived from milk, ghee, and fermented milk products, which are saturated and of animal origin. In contrast to this, the fats in the diets of our Madras group were derived from seed oils, mostly ground-nut or 


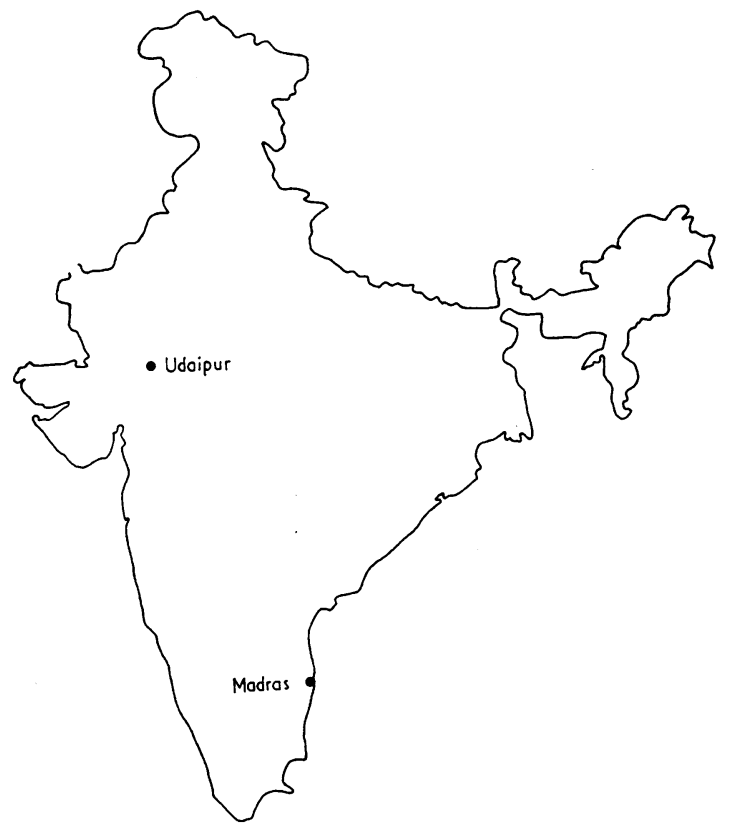

FIG. 1.-Map of India showing Udaipur and Madras.

sesame oil, which have a preponderance of unsaturated fatty acids (Indian Council of Medical Research, 1963). Another important difference in

TABLE I

PATTERN OF FOOD CONSUMPTION OF SWEEPERS IN MADRAS AND UDAIPUR GROUPS: GRAMS PER CONSUMPTION UNIT

\begin{tabular}{|c|c|c|}
\hline Food & Madras (g.) & Udaipur (g.) \\
\hline $\begin{array}{l}\text { Rice } \\
\text { Wheat } \\
\text { Other cereals }\end{array}$ & $\begin{array}{r}425 \\
0 \\
140 \text { (ragi) }\end{array}$ & $\begin{array}{c}0 \\
40 \underset{\text { maize })^{\star}}{440} \text { or }\end{array}$ \\
\hline $\begin{array}{l}\text { Pulses } \\
\text { Leafy vegetables } \\
\text { Non-leafy vegetables }\end{array}$ & $\begin{array}{c}15 \\
0 \\
122 \text { (onions or } \\
\text { brinjal) }\end{array}$ & $\begin{array}{l}62 \\
50 \\
88\end{array}$ \\
\hline Seed oils & 7 (groundnut) & $\begin{array}{l}20 \text { (mustard or } \\
\text { sesame) }\end{array}$ \\
\hline $\begin{array}{l}\text { Ghee } \\
\text { Milk, buttermilk, or curd } \\
\text { Meat and fish }\end{array}$ & $\begin{array}{r}0 \\
12 \\
30 \text { (beef) }\end{array}$ & $\begin{array}{r}55 \\
150 \\
5\end{array}$ \\
\hline $\begin{array}{l}\text { Condiments } \\
\text { Sugar and jaggery } \\
\text { Total calories } \\
\text { Total fats } \\
\text { Calories from fats (\%) } \\
\text { Composition of fats } \\
\text { Saturated fatty acids (\%) }\end{array}$ & $\begin{array}{c}15 \\
12 \\
2334 \\
7 \\
3 \frac{1}{2} \\
\text { Chiefly long- } \\
\text { chain fatty } \\
\text { acids of } \\
\text { seed oils } \\
2\end{array}$ & $\begin{array}{c}5 \\
50 \\
2786 \\
75 \\
23 \\
\text { Chiefly short- } \\
\text { chain fatty } \\
\text { acids of ghee } \\
\text { and milk fats } \\
44\end{array}$ \\
\hline
\end{tabular}

Fats and oils are the amounts of these food stuffs available for consumption as such, not the total amount of fat derived from all dietary constituents.

$\star$ Optional.
TABLE II

MEAN VALUES FOR BLOOD COAGULATION, CLOT RETRACTION, PLATELET NUMBERS, AND PLATELET ADHESIVENESS IN 28 PAIRS OF AGE-MATCHED RAILWAY SWEEPERS (ALL MEN) FROM MADRAS AND UDAIPUR RESPECTIVELY

\begin{tabular}{|c|c|c|c|c|}
\hline Groups & $\begin{array}{l}\text { Clotting } \\
\text { time } \\
\text { (sec.) }\end{array}$ & $\underset{(\%)}{\text { Clot }}$ & $\begin{array}{l}\text { Platelet } \\
\text { count } \\
\left(10^{3}\right)\end{array}$ & $\begin{array}{c}\text { Platelet } \\
\text { adhesive- } \\
\text { ness (\%) }\end{array}$ \\
\hline $\begin{array}{l}\text { Madras: } \\
\text { Mean } \\
\text { Standard error }\end{array}$ & $\begin{array}{l}292 \cdot 0 \\
\pm 9 \cdot 37\end{array}$ & $\begin{array}{r}47.63 \\
\pm 3.96\end{array}$ & $\begin{array}{r}287.65 \\
\pm 15.77\end{array}$ & $\begin{array}{r}21.7 \\
\pm 1.42\end{array}$ \\
\hline $\begin{array}{l}\text { Udxipur: } \\
\text { Mean } \\
\text { Standard error }\end{array}$ & $\begin{array}{l}354 \\
\pm 14 \cdot 34\end{array}$ & $\begin{array}{r}43.87 \\
\pm 4.68\end{array}$ & $\begin{array}{r}293.04 \\
\pm 15.14\end{array}$ & $\begin{array}{r}22 \cdot 75 \\
\pm 1.19\end{array}$ \\
\hline
\end{tabular}

the fats between the two groups is that the dietary fats of our Udaipur group are rich in short-chain fatty acids (Hilditch, 1949), whereas in the seed oils eaten by the Madras group long-chain fatty acids are prominent (Nicholls, 1961).

Apart from these differences, the Udaipur diet is rich in cellulose and vegetable fibres, while the Madras diet lacks these.

The biological significance of these contrasting features of the diets of our two groups with regard to ischaemic heart disease has been discussed elsewhere (Malhotra, 1967a, c).

Blood Studies. These results are summarized in Table II and the tests of significance of these results in Table III. The mean clotting time was longer in our Udaipur group, being 5 minutes and 54 seconds as compared with 4 minutes and 52 seconds in our Madras group. Clot lysis was distinctly more in North Indians than in the South Indians, being present in 23 out of $28(82 \%)$ in Udaipur and only in $8(29 \%)$ in Madras. We also noted that while in the Madras group the clots were firm and compact, these were jelly-like and soft in the Udaipur group. These differences, though less easy to measure quantitatively, were very obvious.

The mean values for platelet numbers, platelet adhesiveness, and clot retraction showed no differences between our two groups (Tables II and III).

\section{Discussion}

Method. In all assay systems with indefinite end-points involving judgement, observer bias is a matter for concern. Experimental error can be considerable in the available tests of blood coagulation, since the results can be influenced by mechanical factors such as differences in syringes and needles, temperature of the water-bath, test-tube size, and the degree of tilting. These defects can be largely offset by increasing the numbers of observations and by the use of "blind studies". In 
TABLE III

ANALYSIS OF DIFFERENCES BETWEEN MEAN VALUES FOR BLOOD COAGULATION, CLOT RETRACTION, PLATELET NUMBERS, AND PLATELET ADHESIVENESS OF CLOT RETRACTION, PLATELET NUMBERS, AND PLATELET
MADRAS VERSUS UDAIPUR SWEEPERS

\begin{tabular}{|c|c|c|c|c|}
\hline & $\underset{\text { time }}{\text { Clotting }}$ & $\begin{array}{c}\text { Clot } \\
\text { retraction }\end{array}$ & $\begin{array}{l}\text { Platelet } \\
\text { counts }\end{array}$ & $\begin{array}{c}\text { Platelet } \\
\text { adhesiveness }\end{array}$ \\
\hline $\begin{array}{l}\text { Difference between means } \\
\text { of Madras and Udaipur } \\
\text { groups }\end{array}$ & $62 \cdot 0$ & 3.76 & $5 \cdot 39$ & 1.05 \\
\hline $\begin{array}{l}\text { Standard error of mean } \\
\text { difference }\end{array}$ & $\begin{array}{c} \pm 17 \cdot 117 \\
\mathrm{t}=3.62 \\
\mathrm{p}<0 \cdot 001 \\
\text { Clotting } \\
\text { time } \\
\text { higher } \\
\text { in } \\
\text { Udaipur } \\
\text { group } \\
\text { than in } \\
\text { Madras } \\
\text { group }\end{array}$ & \multicolumn{3}{|c|}{$\begin{array}{l}\text { No difference in values of Madras } \\
\text { group versus Udaipur group for } \\
\text { clot retraction, platelet counts, } \\
\text { and platelet adhesiveness }\end{array}$} \\
\hline
\end{tabular}

our investigation, therefore, the methods used were identical in the two groups, employing the same syringes and needles, the same test-tubes, and water-bath, and with the same observer reading the end-points in all subjects, who were resting, fasting, and had not smoked or exercised before being bled.

In order to assess the reliability of our observations, we repeated our investigations two months later, the end-points this time being noted by two different observers. These retests were done on 20 unselected sweepers from our original Udaipur group and 24 from our original Madras group. In the retests we used our standard scheme of tilting the test-tubes every half minute (Observer A) as well as the scheme of tilting the tubes every one minute (Observer B), as applied by Eichelberger (1965). The results of the retests were consistent with the results of our main investigation, and showed a mean clotting time of 6 minutes and 4 seconds for the Udaipur group and 4 minutes and 42 seconds for our Madras group when the testtubes were tilted every half-minute $(t=4.30$, $\mathrm{p}<0.001)$. The mean values were 8 minutes and 56 seconds for the Udaipur group and 6 minutes and 1 second for the Madras group when the test tubes were tilted every one minute $(t=5.38, p<0.001)$.

In the retests the mean values for platelet numbers, platelet adhesiveness, and clot retraction, however, showed no significant differences between the two groups as compared with the results of the original investigation.

As a second test of bias in our results we carried out coagulation studies on 21 young North Indian trainees from the Udaipur Railway Training School and a similar number of age-matched young South Indian trainees from the Integral Coach Factory
Training School, Madras (aged 18 to 26 years). These results, in which the end-points were noted by the same observer for both the groups, also showed similar differences between the North Indians versus the South Indians, the respective values being 8 minutes and 49 seconds for the Udaipur trainees as compared with 5 minutes and 55 seconds for the Madras trainees $(p<0.001)$.

Furthermore, in a number of different determinations, e.g. clot retraction, clotting time, platelet numbers, and platelet adhesiveness, even though the same aliquots of blood were used, clotting time showed highly significant and large differences between the two groups, whereas the other determinations, such as clot retraction, platelet numbers, and platelet adhesiveness showed no such differences; from this it is reasonable to conclude that our results of clotting time and clot lysis are independent of any bias in the method of investigation, and, therefore, the significantly large differences in clotting time, clot disintegration, and the quality of clots noted by us are real.

\section{Comments}

It is difficult to interpret the big differences in the clotting times of blood and clot lysis between South Indians and North Indians in this study in relation to the very different incidence of acute myocardial infarction in these two groups, but these seem likely to have biological significance in view of Astrup's (1956) hypothesis that there exists a delicately balanced dynamic equilibrium between coagulation and fibrinolysis, and that disequilibrium might result in atherosclerosis and thrombus formation. The reasons for these large differences in the clotting time and clot lysis between these groups are not 
clear and several alternative explanations must be considered.

Atherosclerosis and Blood Coagulation. While atherosclerosis has been postulated as a major cause of thrombosis, Thomas et al. (1960) have discounted its role in this and have emphasized the importance of haematological factors, though the exact nature of these is still undetermined. Mathur, Patney, and Kumar (1961) and Murthy, Dutta, and Ramalingaswami (1962) found no significant difference in the mean atherosclerotic indices between North Indians and South Indians though these were considerably less than in the West. It seems improbable, therefore, that atherosclerosis was responsible for the significantly different clotting times in the two groups in this study.

Smoking and Blood Coagulation. Smoking can affect blood coagulation (Mustard and Murphy, 1963; Murphy and Mustard, 1966). None of our subjects smoked cigarettes, but there were twice as many biri (a country-made cheroot) smokers in Udaipur (North) as in Madras (South), while those who chewed tobacco were more in the South. In acute experiments both these modes of tobacco consumption were found to decrease the clotting time (Sogani and Joshi, 1965). Our data, however, which are in keeping with the evidence from others (Mustard and Murphy, 1963; Ambrus and Mink, 1964), suggest that smoking, especially habitual smoking, does not have any such effect upon in vitro blood clotting.

Physical Exercise, Blood Clotting, and Clot Lysis. Although there is evidence that physical exertion may affect blood coagulation (Murphy and Mustard, 1966), this does not explain our results because both the groups studied by us were equally active and their work involved a high degree of physical exercise.

According to Ogston and Fullerton (1961), moderate physical exercise increases the fibrinolytic activity of the blood for some hours, but excessive physical exercise by untrained subjects has the opposite effect. Despite the equality of physical activity between our two groups, clot lysis was not only more marked but occurred to a much greater extent in our Northern subjects as compared with our Southern subjects.

Serum Lipids and Blood Coagulation. In South African studies, Merskey and colleagues (1960) found that though serum cholesterol levels were widely different in their Bantu and white South African groups, there were no differences between their clotting times. Our results, on the other hand, showed that while there were big differences in the clotting times between our two groups, there were no differences in the serum levels of total cholesterol, cholesterol esters, free fatty acids, esterified fatty acids, or total serum triglycerides (Malhotra 1967c). Both these observations suggest that blood coagulation has no direct relation with the absolute levels of lipids in the serum, thus supporting the conclusions of Keys et al. (1957), Sohar, Rosenthal, and Adlersberg (1957), and Merskey and Nossel (1957).

Effect of Diet on Blood Clotting. The possible relationship between the dietary differences in our two groups to the differences in clotting time, clot lysis, and the quality of clots remains to be considered. There is good evidence that diet may change some aspects of thrombosis and blood coagulation (Fullerton, Davie, and Anastasopoulos, 1953; Merskey and Nossel, 1957; Sohar et al., 1957; Mustard and Murphy, 1963; Billimoria, 1964). The preponderance of short-chain fatty acids (milk, ghee, and fermented milk products) in the diet of North Indian sweepers as compared with the preponderance of long-chain fatty acids (seed oils) in the diet of South Indian sweepers, indicates a preponderance of short-chain triglyceride acids in North Indians in contrast to the South Indians. As discussed elsewhere (Malhotra 1967a, c), in feeding experiments in man, the triglyceride acids approach the fatty acid composition of fed fats (Ahrens et al., 1958). The presence of cellulose and vegetable fibres in abundance in the diets of our North Indian group and the virtual absence of these from the diets of our South Indian group may accentuate this difference, for cellulose fermentation in the intestine liberates large quantities of acetic acid (Popják, French, and Folley, 1951) which is the precursor of short-chain fatty acids. There is known to be a preponderance of short-chain fatty acids in the plasma of ruminants (Lough, Garton, and Duncan, 1957).

At present this is speculative and demands confirmation by gas chromatographic studies, but it could explain the differences in the clotting times in our two groups. Connor and Poole (1961) and Connor, Hoak, and Warner (1963) reported that, in experimental systems, thrombosis is facilitated by long-chain fatty acids. They found that fatty acids with not less than 16 carbon atoms enhanced thrombosis, whereas short-chain $\left(\mathrm{C}_{6}-\mathrm{C}_{7}\right)$ saturated fatty acids produced virtually no enhancement. Patients with ischaemic heart disease show accelerated clotting times (Thomas et al., 1960; Mustard and Murphy, 1963) and they have been observed also to have an increased proportion (23.8\%) of oleic acid $\left(C_{18: 1}\right)$ in the plasma triglyceride, which could 
account for this difference (Billimoria, 1964). The different results of blood clotting and clot lysis between our two groups may, therefore, be related to the significantly higher incidence of ischaemic heart disease among the South Indian as compared with the North Indian railroad sweepers and may result from the dietary differences in the groups (Malhotra 1967a, c).

In view of the evidence supporting the importance of platelets in thrombosis, the lack of any significant difference in platelet numbers or platelet adhesiveness between our two groups was unexpected and remarkable. The significance of this observation is not yet clear.

\section{SUMMARY}

A study of blood coagulation and clot lysis in two groups of healthy adults, drawn respectively from Northern and Southern India and showing a different incidence of myocardial infarction, showed highly significant differences between the two groups. The mean clotting time was shorter among the Southern Indians than among the Northern Indians. This was not related to clot retraction, platelet numbers, or even platelet adhesiveness. No evidence was found that serum lipid levels, smoking habits, or the amount of exercise had an influence on blood clotting, but it appeared likely that the diet was concerned. It is suspected that the relative proportion of short-chain versus longchain fatty acids in the dietary fats of these two groups may account for the differences in the mean clotting times and the frequency rates of ischaemic heart disease between them. The relevance of the amount of cellulose in the diet is also considered in this connexion.

The coagulation studies were carried out with the technical assistance of Mr. Rasiklal, and platelet studies in association with Dr. N. V. Vaswani of this laboratory, to both of whom I am grateful. Thanks are also due to Professor M. C. Chakrabarti of the Department of Statistics, Bombay University, for his help, to Dr. Alan M. Johnson of Southampton Chest Hospital for helpful criticism of the manuscript, and to Dr. B. J. Cuddigan of the Radcliffe Infirmary, Oxford, for a useful discussion on the nature of the phenomenon of clot lysis described in this paper and published more fully elsewhere.

\section{REFERENCES}

Ahrens, E. H., Jr., Hirsch, J., Insull, W., Jr., and Peterson, M. L. (1958). Dietary fats and human serum lipide levels. In Chemistry of Lipides as Related to Atherosclerosis: A Symposium, pp. 222-261. Ed. by I. H. Page. Charles C. Thomas, Springfield, Illinois.

Ambrus, J. L., and Mink, I. B. (1964). Effect of cigarette smoking on blood coagulation. Clin. Pharmacol. Ther., 5, 428.

2
Astrup, T. (1956). The biological significance of fibrinolysis. Lancet, $2,565$.

Billimoria, J. D. (1964). Dietary factors in relation to clotting mechanisms. In Proc. 6th Int. Congr. Nutrition, Edinburgh 1963, p. 128. Livingstone, Edinburgh.

Connor, W. E., Hoak, J. C., and Warner, E. D. (1963). Massive thrombosis produced by fatty acid infusion. F. clin. Invest., 42, 860 .

-, and Poole, J. C. F. (1961). The effect of fatty acids on the formation of thrombi. Quart. F. exp. Physiol., 46, 1 .

Eichelberger, J. W., Jr. (1965). Laboratory Methods in Blood Coagulation. Harper \& Row, New York.

Fullerton, H. W., Davie, W. J. A., and Anastasopoulos, G. (1953). Relationship of alimentary lipaemia to blood coagulability. Brit. med. F., 2, 250.

Gupta, K. K., and Rai, R. M. (1963). Effect of fats used in Indian diet on cholesterol and blood coagulation. $\mathcal{f}$. Ass. Phycns India, 11, 213.

Hilditch, T. P. (1949). Triglyceride fats in human nutrition. The chemical constitution of natural fats. Brit. $\mathcal{F}$. Nutr., 3, 347.

Indian Council of Medical Research (1963). The nutritive value of Indian foods and the planning of satisfactory diets, p. 141. Spec. Rep. Ser. No. 42.

Keys, A., Buzina, R., Grande, F., and Anderson, J. T. (1957). Effects of meals of different fats on blood coagulation. Circulation, 15, 274.

Lee, R. I., and White, P. D. (1913). A clinical study of the coagulation time of blood. Amer.F. med. Sci., 145, 495.

Lough, A. K., Garton, G. A., and Duncan, W. R. H. (1957). The fatty acid composition of the sterol esters and triglycerides in the plasma of lactating cows. Biochem. F., 65, 31P.

Malhotra, S. L. (1966). The phenomenon of clot-lysis: A preliminary report of a simple rapid test for measuring the dissolution of clots in vitro. f. Ass. Phycns India, 14, 543.

- (1967a). Geographical aspects of acute myocardial infarction in India with special reference to patterns of diet and eating. Brit. Heart $\mathcal{F}$., 29, 337.

- (1967b). Epidemiology of ischaemic heart disease in India with special reference to causation. Brit. Heart F., $29,895$.

- (1967c). Serum lipids, dietary factors and ischemic heart disease. Amer. F. clin. Nutr., 20, 462.

Mathur, K. S., Patney, N. L., and Kumar, V. (1961). Atherosclerosis in India. An autopsy study of the aorta and the coronary, cerebral, renal, and pulmonary arteries. Circulation, 24, 68.

Merskey, C., Gordon, H., and Lachner, H. (1960). Blood coagulation and fibrinolysis in relation to coronary heart disease. A comparative study of normal white men, with overt coronary heart disease, and normal Bantu men. Brit. med. F., 1, 219.

- and Nossel, H. L. (1957). Blood coagulation after the ingestion of saturated and unsaturated fats. Lancet, 1, 806.

Murphy, E. A., and Mustard, J. F. (1966). Tobacco and thrombosis. Amer. F. publ. Hlth, 56, 1061.

Murthy, M. S. N., Dutta, B. N., and Ramalingaswami, V. I. (1962). Aortic atherosclerosis in North India (Delhi area). F. Path. Bact., 83, 135.

Mustard, J. F., and Mu rphy, E. A. (1963). Effect of smoking on blood coagulation and platelet survival in man. Brit. med. F., 1, 846.

Nicholls, L. (1961). Tropical Nutrition and Dietetics, 4th ed., pp. 6, 7. Ed. by H. M. Sinclair and D. B. Jelliffe. Baillière, Tindall and Cox, London. 
Ogston, D., and Fullerton, H. W. (1961). Changes in fibrinolytic activity produced by physical activity. Lancet, 2, 730.

Padmavati, S. (1962). Epidemiology of cardiovascular disease in India. II. Ischemic heart disease. Circulation, 25, 711.

Poole, J. C. F. (1962). Effect of diet and lipemia on coagulation and thrombosis. Fed. Proc., 21, No. 4. Pt. 2, p. 20.

Popják, G., French, T. H., and Folley, S. J. (1951). Utilization of acetate for milk-fat synthesis in the lactating goat. Biochem. F., 48, 411.

Rees, H. M., and Ecker, E. E. (1923). An improved method for counting blood platelets. F. Amer. med. Ass., 80, 621.

Rovatti, B. (1951). Indice d'adhésivité et l'agglutinogramme des plaquettes, nouvelles épreuves pour l'étude des affections hémorragipares et thrombogènes. Sang, 22, 451. (Quoted from Whitby and Britton Disorders of the Blood, 9th ed., p. 761. By C. J. C. Britton. Churchill, London. 1963.)

Sogani, R. K., and Joshi, K. C. (1965). Effect of cigarette and biri smoking and tobacco chewing on blood coagulation and fibrinolytic activity. Indian Heart $\mathcal{F}$., 17, 238.

Sohar, E., Rosenthal, M. C., and Adlersberg, D. (1957). Plasma lipids and coagulation of blood. Amer. F. clin. Path., 27, 503.

Stefanini, M. (1950). The diagnosis of hemorrhagic diseases. Bull. Nerw Engl. med. Cent., 12, 102.

Thomas, W. A., Davies, J. N. P., O'Neal, R. M., and Dimakulangan, A. A. (1960). Incidence of myocardial infarction correlated with venous and pulmonary thrombosis and embolism. Amer. F. Cardiol., 5, 41. 